\title{
Application of multiplex PCR using species- specific primers within the 165 rRNA gene for rapid identification of Nocardioides strains
}

\author{
Yong-Ha Park, ${ }^{1}$ Jung-Hoon Yoon ${ }^{1,2}$ and Sung Taik Lee ${ }^{2}$
}

\footnotetext{
1 Korean Collection for Type Cultures (KCTC), Korea Research Institute of Bioscience \& Biotechnology (KRIBB), PO Box 115, Yusong, Taejon, Korea

2 Department of Biological Sciences, Korea Advanced Institute of Science and Technology, Taejon, Korea
}

Author for correspondence: Sung Taik Lee. Tel: +8242869 2617. Fax: +82428695617. e-mail: stlee@sorak.kaist.re.kr

Keywords: multiplex PCR, 16S rRNA gene, rapid identification, Nocardioides

\section{INTRODUCTION}

The genus Nocardioides was proposed by Prauser (1976) for nocardioform actinomycetes that form a mycelium which fragments into irregular rod- to coccus-like elements. The organisms are Gram-positive, non-acid-fast, aerobic and mesophilic and have a cell wall based on LL-diaminopimelic acid, the diagnostic diamino acid of wall chemotype I (Prauser, 1976). However, the inclusion of previously described Pimelobacter species within the genus Nocardioides and the description of Nocardioides plantarum have rendered the genus morphologically heterogeneous (Collins et al., 1989, 1994). Therefore, additional chemical markers are important to characterize the taxon. The genus Nocardioides has complex cellular fatty acid profiles containing iso-, anteiso-, straight chain, unsaturated and 10-methyl-branched acids. The major fatty acid characterizing the genus is iso- $\mathrm{C}_{16: 0}$ (Miller et al., 1991; O'Donnell et al., 1982; Tamura \& Yokota, 1994). The genus lacks mycolic acids (Prauser, 1976) and has a tetrahydrogenated menaquinone with eight isoprene units $\left[\mathrm{MK}-8\left(\mathrm{H}_{4}\right)\right]$ as the predominant isoprenoid quinone (O'Donnell et al., 1982; Tamura \& Yokota, 1994).

There are currently five validly described Nocardioides species, namely Nocardioides albus (Prauser, 1976), Nocardioides luteus (Prauser, 1984), Nocardioides jensenii (Collins et al., 1989; Suzuki \& Komagata, 1983), Nocardioides plantarum (Collins et al., 1994) and Nocardioides simplex (O'Donnell et al., 1982). Nocardioides fastidiosa was proposed by Collins \& Stackebrandt (1989) but was recently transferred to the genus Aeromicrobium as A. fastidiosum by Tamura \& Yokota (1994).

Recent developments in molecular biology have resulted in new methods that can be used for the identification of micro-organisms. In particular, the introduction of PCR methodology has provided a vast range of techniques for rapid identification or differentiation at species and intraspecies levels (Vandamme $e t$ al., 1996). PCR-based methods, such as randomly amplified polymorphic DNA (RAPD; Welsh \& 
Table 1. Strains used in this study

\begin{tabular}{|c|c|c|}
\hline Laboratory no. & Species & Source* \\
\hline $\mathrm{NSPO}^{\mathrm{T}}$ & Nocardioides albus & КCTC $9186^{\mathrm{T}}$ \\
\hline NSP02 & Nocardioides albus & JCM 5851 \\
\hline NSP03 & Nocardioides albus & JCM 5852 \\
\hline NSP04 & Nocardioides albus & JCM 5853 \\
\hline NSP05 & Nocardioides albus & JCM 5854 \\
\hline NSP06 & Nocardioides albus & JCM 5855 \\
\hline NSP07 & Nocardioides albus & JCM 5856 \\
\hline NSP08 & Nocardioides albus & JCM 5857 \\
\hline NSP09 & Nocardioides albus & JCM 5858 \\
\hline NSP10 & Nocardioides albus & DSM 46107 \\
\hline NSP11 & Nocardioides albus & JCM 5859 \\
\hline NSP12 & Nocardioides albus & JCM 5860 \\
\hline NSP13 & Nocardioides albus & JCM 5861 \\
\hline NSP14 & Nocardioides albus & JCM 5862 \\
\hline NSP15 & Nocardioides albus & JCM 5863 \\
\hline NSP16 & Nocardioides albus & JCM 5864 \\
\hline NSP17 & Nocardioides albus & DSM 43873 \\
\hline NSP18 & Nocardioides albus & DSM 43874 \\
\hline NSP19 $9^{T}$ & Nocardioides jensenii & KCTC $9134^{\mathrm{T}}$ \\
\hline NSP20 $20^{\mathrm{T}}$ & Nocardioides luteus & КСТC $9575^{\mathrm{T}}$ \\
\hline $\mathrm{NSP} 21^{\mathrm{T}}$ & Nocardioides plantarum & NCIMB $12834^{\mathrm{T}}$ \\
\hline $\mathrm{NSP} 22^{\mathrm{T}}$ & Nocardioides simplex & KCTC $9106^{\mathrm{T}}$ \\
\hline NSP23 & Nocardioides simplex & JCM 1366 \\
\hline NSP24 & Nocardioides simplex & JCM 1367 \\
\hline NSP25 & Nocardioides simplex & NCIMB 12919 \\
\hline NSP27 & Nocardioides simplex & ATCC 15799 \\
\hline
\end{tabular}

*ATCC, American Type Culture Collection, Rockville, MD, USA; DSM, Deutsche Sammlung von Mikroorganismen und Zellkulturen, Braunschweig, Germany; JCM, Japan Collection of Microorganisms, Institute of Physical and Chemical Research, Saitama, Japan; KCTC, Korean Collection for Type Cultures, Taejon, Korea; NCIMB, National Collection of Industrial and Marine Bacteria, Aberdeen, UK.

McClelland, 1990; Williams et al., 1990), amplified rDNA restriction analysis (Laguerre et al., 1994; Yoon et al., 1997a) and amplified fragment length polymorphism (AFLP; Zabeau \& Vos, 1993), have attracted much interest because of their universal applicability, simplicity and rapidity. The combination of PCR techniques and synthetic primers designed from particular target genes have also made possible applications in rapid diagnosis and detection of pathogenic micro-organisms from natural samples (Persing et al., 1993). Multiplex PCR is another method based on PCR and specific primers and has been employed for the differentiation and identification of bacterial strains (Bourque et al., 1993; Geha et al., 1994; Yoon et al., 1996b). For instance, multiplex PCR using the $16 \mathrm{~S}$ rRNA gene as the target was recently introduced and successfully applied to the rapid identification of Saccharomonospora strains (Yoon et al., 1996b). The method proved itself to be species-specific, rapid and simple (Yoon et al., 1996b).

In this study, 26 strains of the genus Nocardioides were analysed on the basis of multiplex PCR targeting of the
16S rRNA gene. The usefulness of multiplex PCR analysis for rapid identification of Nocardioides strains was examined.

\section{METHODS}

Bacterial strains. Table 1 summarizes the bacterial strains used in this study. All of the test strains were grown in shake flasks containing trypticase soy broth (BBL) supplemented with glucose $(0.75 \%)$ at suitable temperatures. The broth cultures were checked for purity before they were harvested by centrifugation.

Selection of primers. The forward primers were selected from 16S rDNA sequences of Nocardioides species determined in this laboratory. The single reverse primer was a universal primer corresponding to the $3^{\prime}$ end of $16 \mathrm{~S}$ rDNA. Table 2 summarizes the DNA sequences and annealing positions for PCR primers used in this study.

Isolation of DNA. Chromosomal DNAs were isolated by the method described previously (Yoon et al., 1996a).

PCR. PCR was performed in a final reaction volume of $50 \mu 1$ and the reaction mixture contained $0.5 \mu \mathrm{M}$ each primer, $200 \mu \mathrm{M}$ each dNTP, $50 \mathrm{mM} \mathrm{KCl}, 10 \mathrm{mM}$ Tris $/ \mathrm{HCl}(\mathrm{pH}$ 
Table 2. Primers used in this study

\begin{tabular}{|llcl|}
\hline Primer & \multicolumn{1}{c}{ Sequence $\left(\mathbf{5}^{\prime} \mathbf{3}^{\prime}\right.$ ) } & Position* $^{*}$ & \multicolumn{1}{c|}{ Characteristic } \\
\hline 1fAL & ACCGGATACGACAACCGATT & $174-193$ & Specific to $N$. albus and $N$. luteus \\
2fJE & TGTAAACCTCTTTCAGCGGG & $427-446$ & Specific to $N$. jensenii \\
3fPL & AGGCGGTTCTCTGGCAATGTT & $729-749$ & Specific to $N$. plantarum \\
4fSI & ATAGGGGTCTCTTTGATACT & $1016-1038$ & Specific to $N$. simplex \\
5rE & AGAAAGGAGGTGATCCAGCC & $1542-1525$ & Universal \\
\hline
\end{tabular}

* E. coli $16 \mathrm{~S}$ rRNA numbering.

$8.3), 1.5 \mathrm{mM} \mathrm{MgCl}, 0.01 \%$ gelatin and $1.25 \mathrm{U}$ Taq DNA polymerase (Perkin Elmer). The conditions used for thermal cycling were as follows: denaturation of DNA at $94{ }^{\circ} \mathrm{C}$ for 5 min, followed by 35 cycles consisting of denaturation at $94{ }^{\circ} \mathrm{C}$ for $1 \mathrm{~min}$, primer annealing at $60^{\circ} \mathrm{C}$ for $1 \mathrm{~min}$ and extension at $72{ }^{\circ} \mathrm{C}$ for $2 \mathrm{~min}$. The final cycle included an additional extension time of $10 \mathrm{~min}$ at $72^{\circ} \mathrm{C}$ to ensure full extension of the products. On completion of the reaction, each reaction tube was frozen at $-70^{\circ} \mathrm{C}$ for $10 \mathrm{~min}$ and then the mineral oil was removed with a pipette tip. The PCR products were analysed by electrophoresis of a $5 \mu$ l aliquot of the reaction mixture through a $1.5 \%(\mathrm{w} / \mathrm{v})$ agarose gel in Tris/acetate buffer $(0.04 \mathrm{M}$ Tris/acetate, $0.001 \mathrm{M}$ EDTA, $\mathrm{pH} 8.3$ ) at $100 \mathrm{~V}$ followed by staining with ethidium bromide and visualization of DNA bands by UV transillumination.

\section{RESULTS AND DISCUSSION}

By using the alignment of $16 \mathrm{~S}$ rDNA sequences of Nocardioides species determined recently (Yoon et al., 1998a), species-specific primers were designed. Speciesspecific signature nucleotides or sequence regions were determined from the alignment and were positioned at the $3^{\prime}$ end of primers for PCR. Our recent $16 \mathrm{~S}$ rDNA sequence analysis showed that $N$. luteus exhibited a high level of $16 \mathrm{~S}$ rDNA similarity to strains of $N$. albus: $99.0 \%$ to the type strain of $N$. albus, $100 \%$ to $N$. albus JCM 5854 and $99.0-99.9 \%$ to 16 other $N$. albus strains in the region corresponding to positions 28 1524 (Escherichia coli numbering). 16S-23S internally transcribed spacer sequence analysis has also shown that $N$. luteus is related to strains of $N$. albus (Yoon $e t$ al., 1998b). N. luteus, first published as Nocardioides sp. IMET 7830, was differentiated from $N$. albus by DNA-DNA reassociation analysis and was therefore published as a new species of the genus Nocardioides (Prauser, 1984). However, it has been thought that the taxonomic relationship between $N$. albus and $N$. luteus should be re-evaluated from results of 16S rDNA and $16 \mathrm{~S}-23 \mathrm{~S}$ internally transcribed spacer sequence analyses. Preliminary DNA-DNA reassociation studies showed that $N$. albus strains and $N$. luteus have enough DNA-DNA relatedness to be described as one species, according to the current phylogenetic definition of a species (strains with approx. $70 \%$ or greater DNADNA relatedness; Wayne et al., 1987). Therefore, $N$. albus and $N$. luteus were considered as the same species in this study and primer IfAL annealed at the same position in the 16S rDNAs of both species.
Each primer was tested for primer specificity and size differentiation of the PCR fragment specific for each species. The nucleotide sequences of the four forward primers differ from the corresponding 16S rDNA sequences of non-target species by only a few nucleotides positioned at the $3^{\prime}$ end of primers. Therefore, primer specificity tests, which investigate whether each forward primer anneals at the corresponding sequence regions of non-target species, are an important step. The resultant data showed that each primer set generated species-specific PCR products and nontarget species did not produce PCR products identical to those of target species (Fig. 1). As shown in Fig. 1, primer set 1fAL and 5rE from 16S rDNA yielded a $1353 \mathrm{bp}$ and a $1352 \mathrm{bp}$ PCR product for $N$. albus $\mathrm{NSP} 01^{\mathrm{T}}$ and $N$. luteus $\mathrm{NSP} 20^{\mathrm{T}}$, respectively. However, the two PCR products cannot be differentited by agarose gel electrophoresis (Fig. 1). Primer set 2fJE and 5rE yielded a $1099 \mathrm{bp}$ PCR product for the identification of $N$. jensenii NSP19 ${ }^{\mathrm{T}}, 3 \mathrm{fPL}$ and $5 \mathrm{rE}$ yielded a $827 \mathrm{bp}$ PCR product for $N$. plantarum NSP $21^{\mathrm{T}}$, and 4fSI and $5 \mathrm{rE}$ yielded a 529 bp PCR product for $N$. simplex NSP22 ${ }^{\mathrm{T}}$ (Fig. 1). In this study, several differently sized non-specific background PCR products were generated from certain species other than the target species at which each primer set annealed and their presence could not be completely avoided despite changing the annealing temperature (Fig. 1). These bands, arising through undesired primer annealing, appear weak and differ in size from the species-specific PCR products generated by each primer set (Fig. 1). However, they did not create confusion in discrimination of species-specific PCR products. Moreover, these bands were not found in subsequent multiplex PCR assays which was the ultimate objective of this study (Fig. 2). Since it was shown that each forward primer did not anneal to the corresponding 16S rDNA regions of other non-target species, each primer was found to be species-specific.

For rapid identification, the multiplex PCR assay in which the species-specific forward primers and reverse primer $5 \mathrm{rE}$ were mixed in a single reaction tube was performed for the discrimination of members of the genus Nocardioides. $N$. albus $\mathrm{NSP}^{\mathrm{T}}{ }^{\mathrm{T}}, N$. luteus $\mathrm{NSP} 20^{\mathrm{T}}, N$. jensenii $\mathrm{NSP} 19^{\mathrm{T}}, N$. plantarum NSP2 $1^{\mathrm{T}}$ and $N$. simplex $\mathrm{NSP} 22^{\mathrm{T}}$ were first used as representative strains. The multiplex PCR product profiles of 
(a)

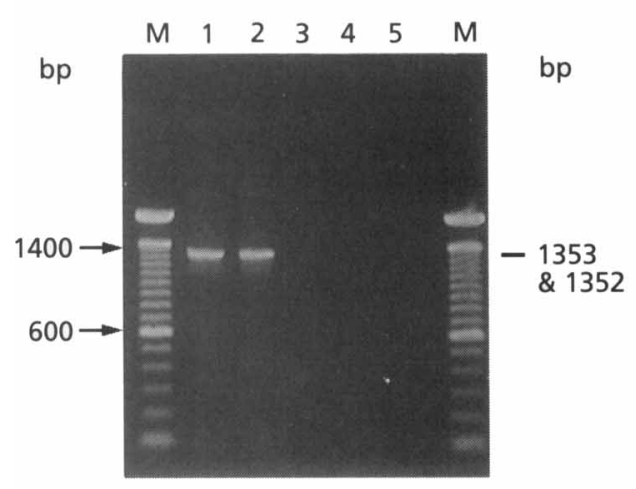

(c)

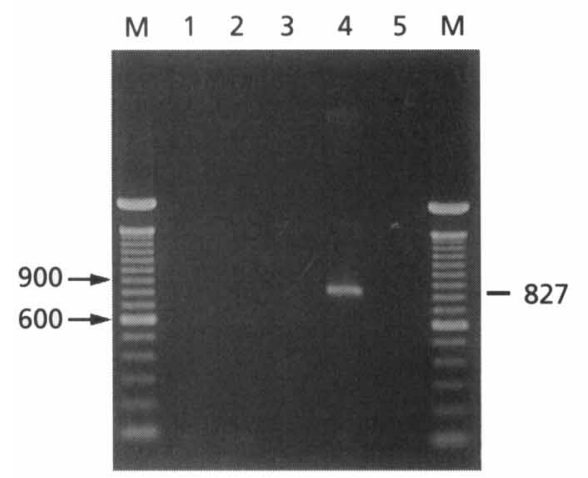

(b)

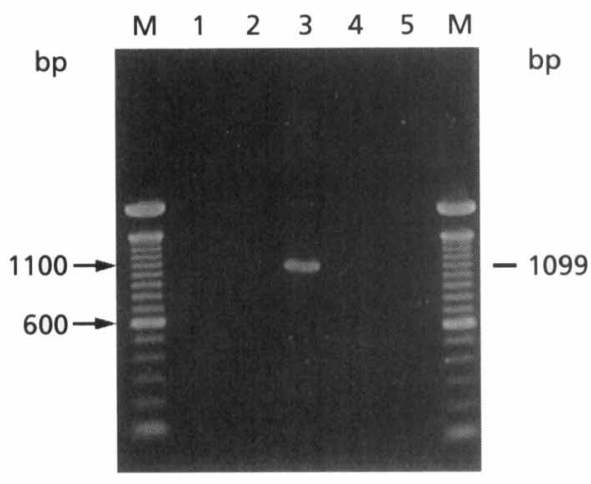

(d)

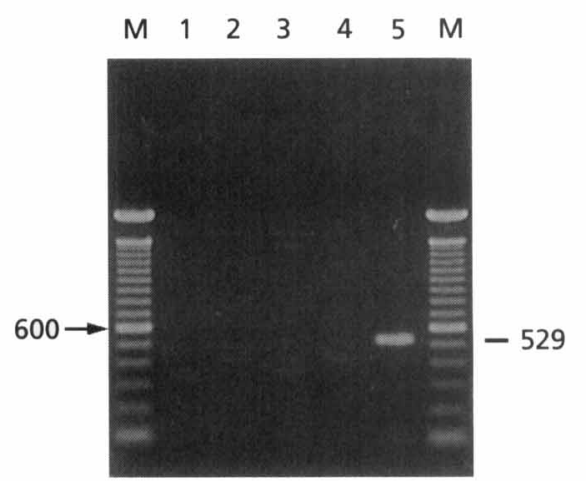

Fig. 1. Agarose gel electrophoresis of amplification products obtained from primer sets $1 \mathrm{fAL}$ and $5 \mathrm{rE}$ (a), $2 \mathrm{fJE}$ and $5 \mathrm{rE}$ (b),


jensenii NSP19 $; 4$, N. plantarum NSP21 ${ }^{\top} ; 5$, N. simplex NSP22 ${ }^{\top}$.

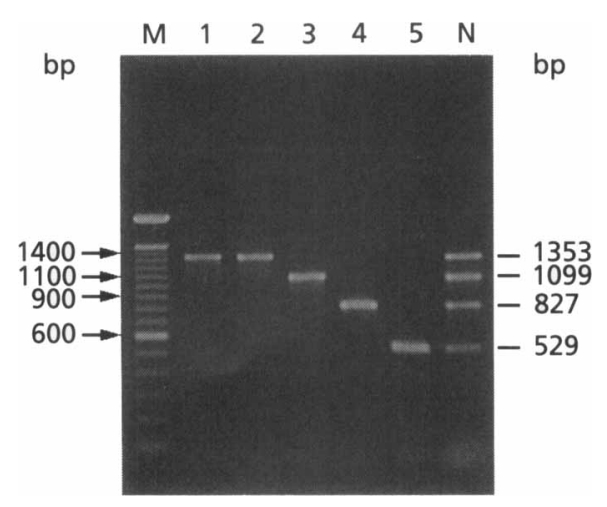

Fig. 2. Agarose gel electrophoresis of amplification products obtained by multiplex PCR from representative strains of the genus Nocardioides. Lanes: $\mathrm{M}, 100 \mathrm{bp}$ DNA ladder (BRL); $1, N$. albus NSPO1 ${ }^{\top} ; 2, N$. luteus $\mathrm{NSP}^{\top} 0^{\top} ; 3, N$. jensenii NSP19 ${ }^{\top} ; 4, N$. plantarum NSP2 $1^{\top} ; 5, N$. simplex NSP22 $2^{\top} ; \mathrm{N}$, species-specific PCR products obtained from four primer sets electrophoresed together.

representative strains of Nocardioides species gave the same results as when individual primer sets were used separately (Fig. 2). The multiplex PCR products of $N$. albus $\mathrm{NSP} 01^{\mathrm{T}}$ and $N$. luteus $\mathrm{NSP} 20^{\mathrm{T}}$ appeared at the same positions (Fig. 2). $N$. jensenii NSP19 ${ }^{\mathrm{T}}, N$. plantarum NSP $21^{\mathrm{T}}$ and $N$. simplex $\mathrm{NSP} 22^{\mathrm{T}}$ gave PCR products of 1099, 827 and 529 bp, respectively (Fig. 2). The representative strains only showed PCR products amplified by primers specific to each Nocardioides species and the PCR products were clearly distinguishable from each other by their different sizes in agarose gel electrophoresis (Fig. 2). The lower part of the agarose gel shows extra non-specific primers which were not annealed to templates (Fig. 2).

Seventeen additional strains previously identified as $N$. albus and four strains previously identified as $N$. simplex were subjected to the multiplex PCR assay. Their multiplex PCR products were compared with those of their corresponding representative strains. The resultant data showed that the additional 17 strains of $N$. albus gave PCR products identical to that of $N$. albus NSP0 $1^{\mathrm{T}}$ (Fig. 3). The sizes of multiplex PCR products of the additional $N$. albus strains may be slightly different from that of $N$. albus $\mathrm{NSP}^{\mathrm{T}}{ }^{\mathrm{T}}$ and may differ from each other because of intraspecific sequence divergence. However, probable size differences are not large enough to be differentiated by agarose gel electrophoresis. The additional four strains 


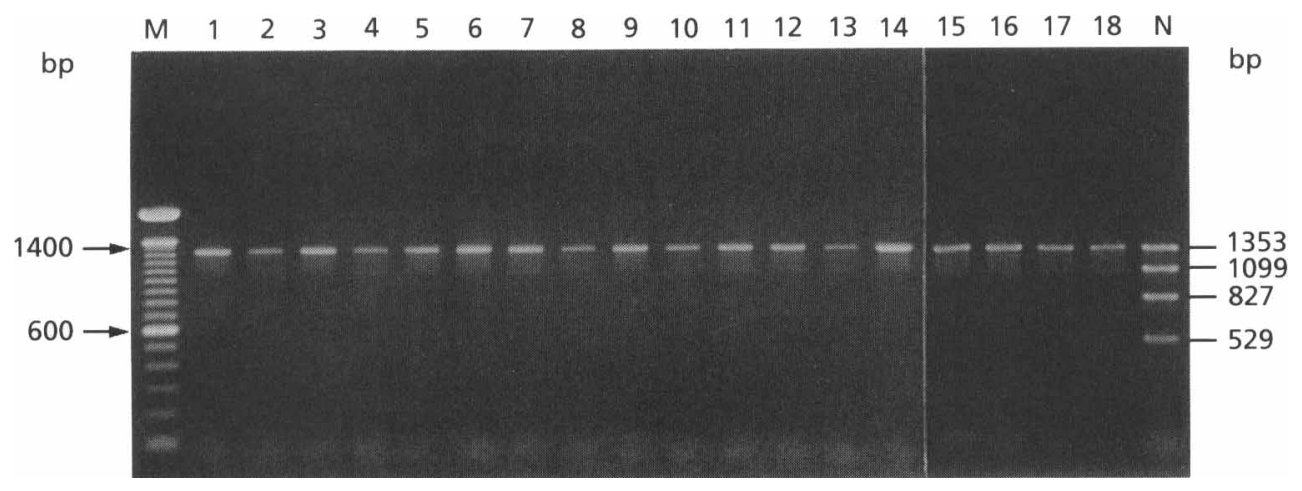

Fig. 3. Agarose gel electrophoresis of amplification products obtained by multiplex PCR from $N$. albus strains. Lanes: $M$, 100 bp DNA ladder (BRL); 1, NSP01'; 2-18, NSP02-NSP18, respectively; N, species-specific PCR products obtained from four primer sets electrophoresed together.

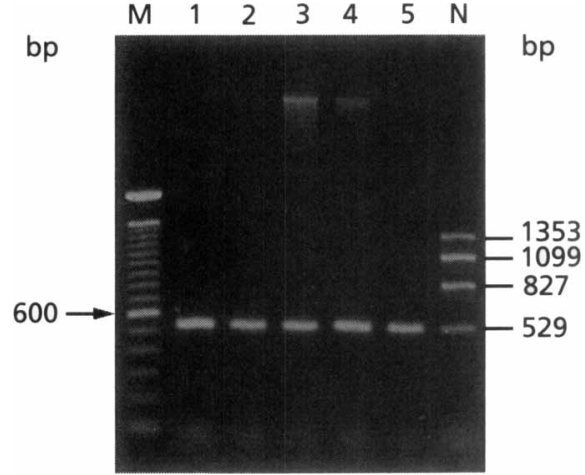

Fig. 4. Agarose gel electrophoresis of amplification products obtained by multiplex PCR from $N$. simplex strains. Lanes: $M$, 100 bp DNA ladder (BRL); $1, \mathrm{NSP}_{2}^{\top} ; 2, \mathrm{NSP} 23 ; 3, \mathrm{NSP} 24 ; 4$, NSP25; 5, NSP27; N, species-specific PCR products obtained from four primer sets electrophoresed together.

of $N$. simplex gave PCR products identical to that of $N$. simplex NSP22 ${ }^{\mathrm{T}}$ (Fig. 4). The type strain and the additional four strains of $N$. simplex used in this study were found to share identical $16 \mathrm{~S}$ rDNA sequences in a recent study (Yoon et al., 1998a). Therefore, our multiplex PCR assay was confirmed as being a speciesspecific method for the identification of $N$. albus and $N$. simplex strains. Other $N$. simplex strains are listed in the American Type Culture Collection (ATCC 13260, ATCC 19565 and ATCC 19566) but these were reclassified as Rhodococcus erythropolis in a previous taxonomic study (Yoon et al., 1997b) and were not used in this study. Since $N$. jensenii and $N$. plantarum are represented by only one strain each, species specificity tests for these species were not performed.

Our multiplex PCR assay was found to be successful in the identification of Nocardioides species. However, $N$. albus strains and $N$. luteus exhibited identical multiplex PCR results (Fig. 2), but these have been shown to be members of the same species by molecular systematic studies (Yoon et al., 1998a, b) and a preliminary DNA-DNA relatedness test. When compared with previous methods, including classical approaches, the multiplex PCR method is very effective in terms of saving time and experimental effort. Recently, it has been reported that the amplification of $16 \mathrm{~S}$ rDNA and multiplex PCR is possible using crude cell lysates extracted from a single colony or from a small quantity of bacterial cells (Frothingham et al., 1991; Hiraishi et al., 1994; Yoon et al., 1996b). This is one of many approaches that make rapid identification possible, although such a trial was not performed in this study.

Bacterial identification to species level is time-consuming and difficult when compared with identification at genus level which is generally possible by studying colonial traits and chemotaxonomic characterization such as isoprenoid quinone composition, fatty acid composition, cell wall composition, etc. (Vandamme et al., 1996). 16S rDNA sequences have been mainly used for phylogenetic identification and classification of bacterial strains (Stackebrandt et al., 1997; Woese, 1987) and such sequencing is performed routinely. Nevertheless, multiplex PCR is thought to have advantages in terms of speed and cost when compared to $16 \mathrm{~S}$ rDNA sequencing. Our multiplex PCR assay is very effective for rapidly identifying large numbers of Nocardioides strains. As discussed previously (Yoon et al., 1996b), the use of the 16S rRNA gene is thought to provide many advantages when compared with other genes. The existence of variable regions together with highly conserved regions (Woese, 1987) and a large amount of information available from databases make the 16S rRNA gene valuable as a target gene for multiplex PCR.

\section{ACKNOWLEDGEMENTS}

This work was supported by grant HS1331 from the Ministry of Science and Technology (MOST) of the Republic of Korea. 


\section{REFERENCES}

Bourque, S. N., Valero, J. R., Mercier, J., Lavoie, M. C. \& Levesque, R. C. (1993). Multiplex polymerase chain reaction for detection and differentiation of the microbial insecticide Bacillus thuringiensis. Appl Environ Microbiol 59, 523-527.

Collins, M. D. \& Stackebrandt, E. (1989). Molecular taxonomic studies on some LL-diaminopimelic acid-containing coryneforms from herbage: description of Nocardioides fastidiosa sp. nov. FEMS Microbiol Lett 57, 289-294.

Collins, M. D., Dorsch, M. \& Stackebrandt, E. (1989). Transfer of Pimelobacter tumescens to Terrabacter gen. nov. as Terrabacter tumescens comb. nov. and of Pimelobacter jensenii to Nocardioides as Nocardioides jensenii comb. nov. Int J Syst Bacteriol 39 , $1-6$.

Collins, M. D., Cockcroft, S. \& Wallbanks, S. (1994). Phylogenetic analysis of a new LL-diaminopimelic acid-containing coryneform bacterium from herbage, Nocardioides plantarum sp. nov. Int J Syst Bacteriol 44, 523-526.

Frothingham, R., Allen, R. L. \& Wilson, K. H. (1991). Rapid 16S ribosomal DNA sequencing from a single colony without DNA extraction or purification. Biotechniques 11, 42-44.

Geha, D. J., Uhl, J. R., Gustaferro, C. A. \& Persing, D. H. (1994). Multiplex PCR for identification of methicillin-resistant staphylococci in the clinical laboratory. $J$ Clin Microbiol 32, 1768-1772.

Hiraishi, A., Shin, Y. K., Ueda, Y. \& Sugiyama, J. (1994). Automated sequencing of PCR-amplified 16S rDNA on 'Hydrolink' gels. J Microbiol Methods 19, 145-154.

Laguerre, G., Allard, M.-R., Revoy, F. \& Amarger, N. (1994). Rapid identification of rhizobia by restriction fragment length polymorphism analysis of PCR-amplified 16S rRNA genes. Appl Environ Microbiol 60, 56-63.

Miller, E. S., Woese, C. R. \& Brenner, S. (1991). Description of the erythromycin-producing bacterium Arthrobacter sp. strain NRRL B-3381 as Aeromicrobium erythreum gen. nov., sp. nov. Int $J$ Syst Bacteriol 41, 363-368.

O'Donnell, A. G., Goodfellow, M. \& Minnikin, D. E. (1982). Lipids in the classification of Nocardioides: reclassification of Arthrobacter simplex (Jensen) Lochhead in the genus Nocardioides (Prauser) emend. O'Donnell et al. as Nocardioides simplex comb. nov. Arch Microbiol 133, 323-329.

Persing, D. H., Smith, T. F., Tenover, F. C. \& White, T. J. (1993). Diagnostic Molecular Microbiology: Principles and Applications. Washington, DC: American Society for Microbiology. Prauser, H. (1976). Nocardioides, a new genus of the order Actinomycetales. Int J Syst Bacteriol 26, 58-65.

Prauser, H. (1984). Nocardioides luteus sp. nov. Z Allg Microbiol 24, 647-648.

Stackebrandt, E., Rainey, F. A. \& Ward-Rainey, N. L. (1997). Proposal for a new hierarchic classification system, Actinobacteria classis nov. Int J Syst Bacteriol 47, 479-491.
Suzuki, K.-I. \& Komagata, K. (1983). Pimelobacter gen. nov, a new genus of coryneform bacteria with LL-diaminopimelic acid in the cell wall. J Gen Appl Microbiol 29, 59-71.

Tamura, T. \& Yokota, A. (1994). Transfer of Nocardioides fastidiosa Collins and Stackebrandt 1989 to the genus Aeromicrobium as Aeromicrobium fastidiosum comb. nov. Int J Syst Bacteriol 44, 608-611.

Vandamme, P., Pot, B., Gillis, M., De Vos, P., Kersters, K. \& Swings, J. (1996). Polyphasic taxonomy, a consensus approach to bacterial systematics. Microbiol Rev 60, 407-438.

Wayne, L. G., Brenner, D. J., Colwell, R. R., Grimont, P. A. D., Kandler, O., Krichevsky, M. I., Moore, L. H., Moore, W. E. C., Murray, R. G. E., Stackebrandt, E., Starr, M. P. \& Trüper, H. G. (1987). Report of the ad hoc committee on reconciliation of approaches to bacterial systematics. Int J Syst Bacteriol 37, 463-464.

Welsh, J. \& McClelland, M. (1990). Fingerprinting genomes using PCR with arbitrary primers. Nucleic Acids Res 18, 7213-7218.

Williams, J. G. K., Kubelik, A. R., Livak, K. J., Rafalski, J. A. \& Tingey, S. V. (1990). DNA polymorphisms amplified by arbitrary primers are useful as genetic markers. Nucleic Acids Res 18, 6531-6535.

Woese, C. R. (1987). Bacterial evolution. Microbiol Rev 51, 221-271.

Yoon, J.-H., Kim, H., Kim, S.-B., Kim, H.-J., Kim, W. Y., Lee, S. T., Goodfellow, M. \& Park, Y.-H. (1996a). Identification of Saccharomonospora strains by the use of genomic DNA fragments and rRNA gene probes. Int $J$ Syst Bacteriol 46, 502-505.

Yoon, J.-H., Lee, S. T., Shin, Y. K., Kim, S.-B., Kim, H.-J., Goodfellow, M. \& Park, Y.-H. (1996b). Rapid identification of Saccharomonospora strains by multiplex PCR using speciesspecific primers within the $16 \mathrm{~S}$ rRNA gene. J Microbiol Methods 27, 89-95.

Yoon, J.-H., Lee, S. T., Kim, S.-B., Kim, W. Y., Goodfellow, M. \& Park, Y.-H. (1997a). Restriction fragment length polymorphism analysis of PCR-amplified 16S ribosomal DNA for rapid identification of Saccharomonospora strains. Int J Syst Bacteriol 47, 111-114.

Yoon, J.-H., Lee, J.-S., Shin, Y. K., Park, Y.-H. \& Lee. S. T. (1997b). Reclassification of Nocardioides simplex ATCC 13260, ATCC 19565 and ATCC 19566 as Rhodococcus erythropolis. Int J Syst Bacteriol 47, 904-907.

Yoon, J.-H., Lee, S. T. \& Park, Y.-H. (1998a). Inter- and intraspecific phylogenetic analysis of the genus Nocardioides and related taxa based on 16S rDNA sequences. Int $J$ Syst Bacteriol 48, 187-194.

Yoon, J.-H., Lee, S. T. \& Park, Y.-H. (1998b). Genetic analyses of the genus Nocardioides and related taxa based on $16 \mathrm{~S}-23 \mathrm{~S}$ rDNA internally transcribed spacer sequences. Int $J$ Syst Bacteriol 48, 641-650.

Zabeau, M. \& Vos, P. (1993). Selective restriction fragment amplification: a general method for DNA fingerprinting. European Patent Office, patent no. 0534858 A1. 